This item was submitted to Loughborough's Research Repository by the author.

Items in Figshare are protected by copyright, with all rights reserved, unless otherwise indicated.

\title{
When are excessive prices unfair?
}

PLEASE CITE THE PUBLISHED VERSION

http://dx.doi.org/10.1093/joclec/nhq024

PUBLISHER

(c) Oxford University Press

VERSION

AM (Accepted Manuscript)

LICENCE

CC BY-NC-ND 4.0

REPOSITORY RECORD

Akman, Pinar, and Luke Garrod. 2019. "When Are Excessive Prices Unfair?". figshare.

https://hdl.handle.net/2134/14708. 
This item was submitted to Loughborough's Institutional Repository (https://dspace.lboro.ac.uk/) by the author and is made available under the following Creative Commons Licence conditions.

\section{creative
commons}

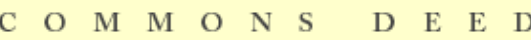

Attribution-NonCommercial-NoDerivs 2.5

You are free:

- to copy, distribute, display, and perform the work

Under the following conditions:

Attribution. You must attribute the work in the manner specified b the author or licensor.

Noncommercial. You may not use this work for commercial purposes.

No Derivative Works. You may not alter, transform, or build upon this work.

- For any reuse or distribution, you must make clear to others the license terms of this work.

- Any of these conditions can be waived if you get permission from the copyright holder.

Your fair use and other rights are in no way affected by the above.

This is a human-readable summary of the Leqal Code (the full license).

\section{Disclaimer 만}

For the full text of this licence, please go to: http://creativecommons.org/licenses/by-nc-nd/2.5/ 


\title{
When Are Excessive Prices Unfair?
}

\author{
Pinar Akman* and Luke Garrod ${ }^{\dagger}$
}

\begin{abstract}
A dominant firm can abuse its position by charging unfair prices under EU competition law. According to the ECJ in United Brands, a price is abusive if (i) the price-cost margin is excessive and (ii) the price is unfair compared to other prices. However, there is little guidance to determine whether a price-cost margin is excessive and if so, when the price is unfair. We consider whether the principle of dual entitlement, which is consistent with most people's perceptions of when prices are unfair relative to others, can be used to define explicitly what constitutes an unfair price in terms of the second stage of the United Brands test. We show that in general this principle is in line with the goals of an effective prohibition of unfairly high pricing and we develop a procedure that defines a price as unfair in terms of this principle. We also show that European competition law enforcers in their attempts to define prices as unfair relative to other prices have followed arguments similar to the procedure developed here. Therefore, this procedure could go some way to resolve one of a number of problems regarding the prohibition of unfairly high pricing.
\end{abstract}

JEL: K21, L40

Keywords: unfair pricing prohibition, dual entitlement, abuse of dominant position

Acknowledgement: We are grateful for comments from Christopher Engel, Morten Hviid, Bruce Lyons, Steve Martin, Alexander Morell and Catherine Waddams on early versions of this paper. We have also benefitted from comments received from seminar participants at the ESRC Centre for Competition Policy, Max Planck Institute for Research on Collective Goods, Competition Law and Economics European Network (CLEEN) Workshop 2009 and American Economic Association (AEA) Annual Meeting 2010. We would also like to thank the anonymous referee for helpful suggestions. The support of the Economic and Social Research Council (UK) is gratefully acknowledged. The usual disclaimer applies.

\footnotetext{
* Corresponding author: Norwich Law School and ESRC Centre for Competition Policy, University of East Anglia, email: p.akman@uea.ac.uk

† ESRC Centre for Competition Policy, University of East Anglia, email: l.garrod@uea.ac.uk
} 


\section{INTRODUCTION}

Article 102 of the Treaty on the Functioning of the European Union (TFEU) regulates unilateral market power in EU competition law, and subparagraph (a) explicitly stipulates that abuse of a dominant position may consist in 'imposing unfair purchase or selling prices'. This has been used to prohibit (exploitative and exclusionary) prices that are unfairly high, and (exclusionary) predatory prices that are unfairly low. In contrast to predatory pricing, the abuse of unfairly high pricing has remained underdeveloped conceptually and in practice at the EU level. According to the European Court of Justice (ECJ) in United Brands a price is abusive if 'it has no reasonable relation to the economic value of the product', and an abuse can be determined by a twofold test that considers whether (i) the pricecost margin is excessive and (ii) the price imposed 'is either unfair in itself or when compared to competing products'. ${ }^{1}$ Thus, the excess in the price-cost margin itself is not determinative. ${ }^{2}$ The European Commission followed this test in Scandlines and highlighted a number of difficulties. It was argued that even if it were possible to prove that a price-cost margin is excessive, there is little guidance to determine whether a price is 'unfair' when comparisons are drawn, as per the second stage of the United Brands test, if it is possible to make such comparisons at all. ${ }^{3}$

Due to such difficulties, there have been a number of attempts to establish a test that can determine whether a price-cost margin is excessive that can be used to operationalise the first stage of the United Brands test. ${ }^{4}$ In contrast, there has been little research into determining whether a price with an excessive price-cost margin is 'unfair' when compared to itself and/or other relevant prices under the second stage of the United Brands test. This article attempts to fill this gap in the literature. Given that Article 102(a)TFEU prohibits 'unfair' prices and not merely prices with excessive price-cost margins, establishing the 'unfair' nature of an allegedly abusive price is crucial for the correct interpretation of the law. ${ }^{5}$

In United Brands the ECJ stated that economists have developed ways to determine whether a price is 'unfair' and such methods could be used to define a price as abusive. ${ }^{6}$ Although this was optimistic at the time, more recent advances in the economics of fairness have furthered our understanding of when prices are perceived as unfair. In this paper we consider whether one such advance - the 'principle of dual entitlement' - can be applied constructively to aid the interpretation of this area of law where conventional economic theory is unhelpful. ${ }^{7}$ This principle states that transactors are 'entitled' to the terms of trade of a reference transaction, and it is 'unfair' if a firm charges a price that relative to the reference realises a gain for the firm at the expense of its customers' entitlement. Given that it can explain when and why a price is unfair relative to another, it is a natural candidate to be used to define a price as unfair in the second stage of the United Brands test if it is consistent with the aims of an unfairly high pricing prohibition.

We show that in general the principle of dual entitlement is aligned with the goals of an effective prohibition of unfairly high prices, because it states that, other things equal, a higher price is unfair if caused by a lack of competition but it is not if due to the firm's production costs. Using this principle, we outline a simple procedure to determine when a price with an excessive price-cost margin is unfair and compare this with some examples from the case law. We find that European competition law enforcers have followed similar arguments in their attempts to define prices as unfair when compared to others, but disparities occur in attempts to define prices as 'unfair in themselves'. Therefore, this procedure may go some way to resolve one of a number of problems regarding the prohibition of unfairly high prices, because it provides some objectivity to the second stage of the United Brands test which will provide greater ex ante legal certainty of the test and could lead to a

\footnotetext{
${ }^{1}$ Case 27/76 United Brands Company and United Brands Continental BV v EC Commission [1978] ECR 207, paras 250-252.

${ }^{2}$ United Brands, above n 1, paras 250-252. In the UK, the Competition Appeal Tribunal (CAT) has stated excessiveness to be a necessary-but-not sufficient condition in Case 1046/2/4/04 Albion Water Ltd and Albion Water Group Ltd v Water Services Regulation Authority [2008] CAT 31, para 7.

${ }^{3}$ Scandlines Sverige AB v Port of Helsingborg Commission Decision (Case COMP/A.36.568/D3) 23.07.2004 (unreported) paras 163,169 , et seq.

${ }^{4}$ For some of the methods see e.g. R O’Donoghue and A.J. Padilla, The Law and Economics of Article 82 EC, (Oxford: Hart Publishing 2006) 613 et seq.

${ }^{5}$ As long as it is not a direct reference to the prohibition in the TFEU, this article refers to the prohibition as an 'unfairly high pricing prohibition' instead of an 'excessive' or 'unfair' pricing prohibition to avoid any confusion between the prohibition and the two steps of the United Brands test. In the UK, the CAT adopted the same terminology in Albion, above $\mathrm{n} 2$, para 7.

${ }^{6}$ United Brands, above n 1, para 253.

${ }^{7}$ For the principle of dual entitlement see D. Kahneman, J.L. Knetsch and R.H. Thaler, 'Fairness as a Constraint on Profit Seeking: Entitlements in the Market’, (1986) 76 (4) American Economic Review 728 [1986a] and D. Kahneman, J.L. Knetsch and R.H. Thaler, 'Fairness and the Assumptions of Economics', (1986) 59 (4) Journal of Business S285 [1986b].
} 
more effective prohibition. As a result, this procedure may help in solving a problem that has been described as a 'daunting, if not, impossible task' by Evans and Padilla. ${ }^{8}$

The difficulties arising from the second stage of the United Brands test could theoretically be overcome by eliminating this stage, as proposed by Motta and de Streel who interpret an abusive price under Article 102(a)TFEU as one significantly above the minimum average cost. ${ }^{9}$ Although this would simplify the analysis necessary to determine an abuse, there are advantages that would be lost if such an approach were followed. For instance, there will be greater uncertainty for firms regarding what constitutes an abuse when they set prices, because abusive levels are not common knowledge before a case is brought as these are (sensibly) decided on a case-by-case basis. In contrast, the two-staged test provides at least some guidance, because prices similar to those in comparable (competitive) markets should not be abusive. Furthermore, the one-staged test is less adept at capturing unwarranted conduct. For example, consider a monopolist that optimally charges the same price over two periods, but in the second period it is more efficient and supplies a product that better suits its consumers' preferences. If the second stage is ignored, an abuse will be found if the price-cost margin is deemed excessive. If comparisons are also drawn over time, however, such an outcome seems less likely because the price has not changed and the firm's conduct has led to extra benefits for the firm and its customers. It must also be pointed out that the ECJ's holding in United Brands is clear in requiring there to be more than excessiveness and the TFEU is clear in requiring 'unfairness' for the price to be abusive. Thus, a test based on merely the first stage of United Brands would go against the case-law and the TFEU. Consequently, improving the existing two-staged test is at least as important as proposing alternative tests. ${ }^{10}$

Certain adverse effects of a prohibition of unfairly high pricing will remain even if there is a well-defined test. For instance, problems regarding exploitation will only be resolved if remedies restrict the firm's future conduct or change the structure of the market. In the EU the most likely remedy is the former, because the European Commission can only impose structural remedies either where there is no equally effective behavioural remedy or where such a behavioural remedy is more burdensome for the firm. ${ }^{11}$ Behavioural remedies for unfairly high pricing usually amount to price regulation, which is the 'antithesis of the free market' ${ }^{12}$ and it is questionable whether competition agencies have the required skills and resources to impose it effectively. ${ }^{13}$ A further problem is that a prohibition of unfairly high pricing can distort firms' dynamic incentives to compete, because they may be unable to reap the rewards of their successes in the future. Evans and Padilla argue that this can be exacerbated if there are more Type I errors (false-convictions) than Type II errors (false-acquittals), because Type I errors affect the whole economy as firms in all industries may be concerned of false convictions; ${ }^{14}$ whereas the effects of Type II errors are smaller because high prices should eventually attract entry. ${ }^{15}$

Due to such adverse effects, it has been argued that it is best to adopt a per se legality approach to pricing. ${ }^{16}$ While it may be necessary to limit the number of cases where the prohibition is implemented to avoid adverse effects, such a stance requires an amendment to the Treaty which is unlikely in the near future. Furthermore, it would also rule out the possibility of interventions in exceptional circumstances where such adverse effects are minimal and direct harm to consumers may persist in the long run in the absence of intervention. Motta and de Streel argue that an example of such a situation is where there are high entry barriers and a firm's dominant position was attained in a

\footnotetext{
${ }^{8}$ D.S. Evans and A.J. Padilla, ‘Excessive Prices: Using Economics to Define Administrable Legal Rules’, (2005) 1 (1) JOCLEC 97, at 118 .

${ }_{9}^{9}$ M. Motta and A. de Streel, 'Excessive Pricing and Price Squeeze under EU Law' in C.D. Ehlermann and I. Atanasiu (eds), European Competition Law Annual 2003: What Is an Abuse of a Dominant Position? (Oxford: Hart Publishing 2006) 94. In another article, Motta and de Streel interpret the decision in United Brands to imply that only the first stage needs to be fulfilled for the price to be abusive. The second stage is only necessary when it is infeasible to conduct the price-cost analysis; see M. Motta and A. de Streel, 'Excessive Pricing in Competition Law: Never say Never?' in The Pros and Cons of High Prices (Swedish Competition Authority, Kalmar: Lenanders Grafiska 2007) 39. As they point out, this view differs to most other commentators; ibid.

${ }^{10}$ Difficulties could also be overcome if the law focused on features that distort effective competition in a market (the cause) rather than the excessiveness of the price (the effect). An example of such a mechanism is the market investigations under the Enterprise Act 2002 in the UK. However, the European Commission does not have the power to impose remedies on a market as a whole after a sector inquiry.

${ }^{11}$ Regulation 1/2003 on the implementation of the rules on competition laid down in Articles 81 and 82 of the Treaty, [2003] OJ L1, 1 , Article 7.

${ }^{12}$ A. Jones and B. Sufrin, EC Competition Law: Text, Cases, and Materials (3rd ed, Oxford: Oxford University Press 2008$) 586$.

${ }^{13}$ W. Blumenthal, 'Discussant Comments on Exploitative Abuses under Article 82 EC' in C.D. Ehlermann and M. Marquis (eds), European Competition Annual 2007: A Reformed Approach to Article 82 EC (Oxford: Hart Publishing 2008$) 578$.

${ }^{14}$ Evans and Padilla, above $\mathrm{n}$ 8, at 114.

${ }^{15}$ See F.H. Easterbrook, 'The Limits of Antitrust', (1984) 63 (1) Texas Law Review 1, at 2.

${ }^{16}$ Evans and Padilla, above n 8, at 118.
} 
market before competition was introduced, rather than reached by investment, innovation or business luck. ${ }^{17}$ Similarly, Röller argues that, in the absence of appropriate structural remedies and an effective regulatory agency, the prohibition should be used for cases where dominance results from anticompetitive practices not covered by EU competition law or from a lack of prior effective enforcement by the competition authority. ${ }^{18}$ Given that such exceptional circumstances may exist and the Commission has the power to intervene in them, it is important that there is a test to determine an abuse that is as effective as possible to limit the number of Type I and II errors.

Unfairly high pricing by a dominant firm is an area of competition law where the respective laws in Europe and the US diverge, because US antitrust law does not prohibit exploitative practices as such. This was recently made very clear by the US Supreme Court in the context of monopoly pricing in Verizon:

the mere possession of monopoly power, and the concomitant charging of monopoly prices, is not only not unlawful; it is an important element of the freemarket system. ${ }^{19}$

Despite this difference in competition policies, the European prohibition of unfairly high pricing is of interest in both sides of the Atlantic because US multinationals operating within Europe are bound by EU competition law. This is evident by the European Commission's recently announced unfair pricing case against the US-firm Standard \& Poor's and the commitment accepted from Rambus to decrease the level of its royalties. ${ }^{20}$ Such cases are only likely to intensify the debate on the pros and cons of an unfairly high pricing prohibition.

The article is structured as follows: Section II compares the United Brands test to the criteria for an effective test of unfairly high pricing. Section III analyses whether using the principle of dual entitlement to define a price as unfair is consistent with the aims of an unfairly high pricing prohibition. Section IV develops a simple procedure to determine whether a price is 'unfair' in terms of dual entitlement, and considers how this fares against the criteria for an effective test of unfairly high pricing. Section $\mathrm{V}$ discusses three case studies to find how the procedure compares with the existing case law on unfairly high pricing. Finally, Section VI concludes.

\section{AN EFFECTIVE TEST OF UNFAIRLY HIGH PRICING}

In this Section we make explicit the features of an effective test of unfairly high pricing to demonstrate the problems of the United Brands test and to use as a benchmark to highlight how the procedure in this paper might improve the law. In general, any legal prohibition should have a deterrence effect and should include a test that correctly establishes the existence or lack of breach. To achieve these aims, an effective test of unfairly high pricing should satisfy four criteria: it should (i) be well-defined; (ii) provide ex ante legal certainty; (iii) be simple to implement; and (iv) improve welfare. The first three criteria relate to the definition of an abuse, whereas the last criterion mainly concerns remedies. Henceforth, we take as given that an appropriate remedy can be implemented if a price is found to be abusive, and that the prohibition is implemented in situations where adverse effects regarding investment and innovation are minimised.

\section{A. Clear definition}

There needs to be a clear definition regarding what constitutes an abuse and of any other parameter that determines an abuse. In terms of the current law, this condition is not satisfied since the definition of an abuse as a price that 'has no reasonable relation to the economic value of the product' leaves undefined terms such as 'reasonable' and 'economic value'. Moreover, there is no definition of 'excessive' or 'unfair' in the context of the United Brands test.

\footnotetext{
${ }^{17}$ Motta and de Streel (2006), above n 9, at 109.

${ }^{18}$ L.H. Röller, 'Exploitative Abuses', in C.D. Ehlermann and M. Marquis (eds), European Competition Annual 2007: A Reformed Approach to Article 82 EC (Oxford: Hart Publishing 2008) 528 et seq. For other examples see B. Lyons, 'The Paradox of the Exclusion of Exploitative Abuse' in The Pros and Cons of High Prices (Swedish Competition Authority, Kalmar: Lenanders Grafiska 2007); A. Fletcher and A. Jardine, 'Towards an Appropriate Policy for Excessive Pricing' in C.D. Ehlermann and M. Marquis (eds), European Competition Annual 2007: A Reformed Approach to Article 82 EC (Oxford: Hart Publishing 2008).

${ }^{19}$ Verizon Communications Inc v Law Offices of Curtis v Trinko LLP 540 US 398, 407, 124 S Ct 872 (2004).

${ }^{20}$ See EU Commission Press Release 'Commission confirms sending Statement of Objections to Standard \& Poor's' 19 November 2009, MEMO/09/508. For the Rambus commitment, see EU Commission Press Release 'Commission accepts commitments from Rambus lowering memory chip royalty rates’ 9 December 2009, IP/09/1897.
} 


\section{B. Ex ante legal certainty}

This condition requires that a test is known by firms before they make their pricing decisions, which informs them of which prices will be an infringement of the law or which will not. The existing law fails this criterion for two reasons. First, it fails to provide any certainty regarding the conditions for the application of the prohibition. For example, it is unclear whether it applies to all dominant firms or only in special cases where potential adverse effects are minimised. Second, in advance of a breach it is uncertain which prices are abusive. Although the second stage of the United Brands test is helpful in this aspect, firms are still unsure which comparisons will be used or how similar the prices should be to avoid a breach of the prohibition.

\section{Simplicity}

A test is simple to implement if the enforcer can collect the relevant information required on the variables of the test, and it can determine whether the price is abusive from this. This criterion is not satisfied because in some situations information may not be readily available and there are likely to be difficulties regarding calculation of economic profit from accounting data. Moreover, even when all the relevant information is available, it is difficult to determine whether a price has no reasonable relation to the economic value of the product, because there is little guidance for determining when the pricecost margin is excessive and when a price is unfair when comparisons are drawn.

\section{Improve welfare}

The current law would improve welfare if it prevented and deterred dominant firms from exploiting consumers in the long run with minimal adverse effects on investment and innovation. Due to the problems with the United Brands test, it is likely that any case brought on grounds of (exploitative) unfair pricing will be unsuccessful. Therefore, if there is any deterrence effect at all, it will be small and, although Type I errors will be rare, it will also be extremely difficult to intervene to prevent direct harm to consumers in the exceptional circumstances where adverse effects of intervention are minimal. Moreover, compared to a per se legality approach, welfare will be reduced due to litigation costs.

\section{III. $\quad$ UNFAIR PRICING PROHIBITION AND DUAL ENTITLEMENT}

Kahneman et al show that the principle of dual entitlement can explain when and why people perceive price, rent and wage levels as unfair relative to comparable transactions. ${ }^{21}$ In this Section, we consider whether it is desirable to use the principle of dual entitlement to determine whether a price is unfair in the second stage of the United Brands test, and we highlight potential problems to be overcome for this to be the case. Since we are only interested in the unfairness of prices with respect to competition issues, only a subset of their findings regarding the psychology of unfairness will be relevant for our purposes.

\section{A. The principle of dual entitlement}

The principle of dual entitlement states that a firm and its customers are entitled to the terms of trade of a given reference transaction. It is unfair for a firm to charge a price that impinges upon the entitlement of its customers to realise a potential gain for itself. If market conditions change, it is not unfair for a firm to set worse terms of trade than the reference transaction to maintain (at most) its own entitlement.

Kahneman et al suggest that people use a number of reference points when forming opinions of price fairness, and that disagreements over what is unfair can arise because people focus on different

\footnotetext{
${ }^{21}$ Kahneman et al (1986a), above n 7. The principle of dual entitlement has inspired a wide range of research. Regarding pricing, the literature mainly considers consumers' reactions to unfair conduct (see J. Urbany, T.J. Madden and P.R. Dickson, 'All's Not Fair in Pricing: An Initial Look at the Dual Entitlement Principle’, (1989) 1 Marketing Letters 17; M. Rabin, 'Incorporating Fairness into Game Theory’, (1993) 93 American Economic Review 1281; R. Franciosi, P. Kujal, R. Michelitsch, V. Smith and G. Deng, 'Fairness: effect on temporary and equilibrium prices in posted-offer markets', (1995) 105 Economic Journal 938; R. Piron and L. Fernandez, ‘Are Fairness Constraints on Profit-Seeking Important?’, (1995) 16 Journal of Economic Psychology 73; and J. Rotemberg, 'Customer Anger at Price Increases, Changes in the Frequency of Price Adjustment and Monetary Policy', (2005) 52 Journal of Monetary Economics 829). The management literature proposes ways in which firms can minimise the effects of such behaviour (see L. Xia, K.B. Monroe and J.L. Cox, 'The Price Is Unfair! A Conceptual Framework of Price Fairness Perceptions’ (2004) 68 Journal of Marketing 1 for a review).
} 
reference points. ${ }^{22}$ Such natural comparators are the firm’s past prices or other current prices involving the firm or its competitors on comparable markets. This comparison provides a basis for fairness judgements because it is normal, not necessarily because it is just, so potentially a price that is initially perceived as unfair may become the reference transaction in the future. In terms of measuring gains and losses, Kahneman et al do not explicitly specify units but in general they consider firm gains in terms of profit and consumer gains in terms of the price, assuming other factors are constant.

Figure 1. An illustration of the principle of dual entitlement

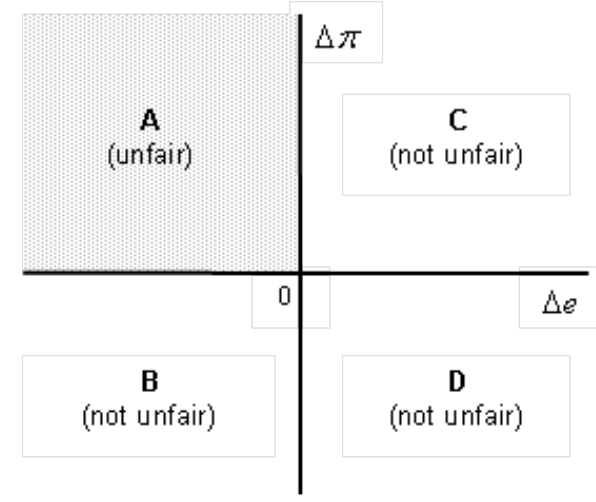

With such units in mind, dual entitlement can be illustrated as in Figure 1 where $\Delta \pi$ and $\Delta \mathrm{e}$ are measures of the change in the firm's and its customers' gains due to the price charged relative to the reference transaction, respectively. For example, if the reference transaction is the firm's previous price and an adjustment is necessary due to an exogenous shock to the market, the new price is unfair if the firm gains at its customers' expense (area A) but it is not unfair if the firm's gain also leads to gains for its customers (area C). If the firm does not gain the price is not unfair whether the customers gain (area D) or not (area B). There is no change to the firm's or its customers' entitlement at the origin (0).

\section{B. Implications for pricing}

To provide evidence of the principle of dual entitlement, Kahneman et al present the results of a survey that considered the fairness of hypothetical situations where prices lead to (i) a gain to the firm at the expense of its customers; (ii) no gain to the firm at the expense of its customers; and (iii) a gain to the firm that is not at the expense of its customers. ${ }^{23}$ In Figure 1, these three groups refer to areas A, B and $\mathrm{C}$, respectively. There was no analysis of situations that fall in area D because it is uncontroversial with respect to fairness towards consumers. ${ }^{24}$ Using examples from this survey, we consider the implications for a test of unfair pricing if prices are defined as 'unfair' using the principle of dual entitlement. We consider situations (i)-(iii) in turn.

\section{Gain to the firm at the expense of its customers}

The principle of dual entitlement deems a price as unfair if the level is higher than the reference transaction due to exploitation of market power, because the firm gains at its customers' expense. To highlight the point, an example provided by Kahneman et al asked respondents to consider one such scenario:

A grocery chain has stores in many communities. Most of them face competition from other groceries. In one community the chain has no competition. Although its

\footnotetext{
${ }^{22}$ Kahneman et al (1986a), above n 7, 730.

${ }^{23}$ Kahneman et al (1986a), above n 7. Kahneman et al (1986a) surveyed a random population of Toronto and Vancouver. Similar results are found by B.S. Frey and W.W. Pommerehne, 'On the fairness of pricing -- An empirical survey among the general population', (1993) 20 Journal of Economic Behavior and Organization 295 who replicated the survey in West Berlin and Zurich.

${ }^{24}$ An outcome in area D could be unfair towards firms. It is not of interest to this paper because dominant firms are price makers so they are unlikely to set prices that are unfair towards themselves. Further, since it is not unfair for a firm to maintain its reference profit and even increase its profit without impinging upon the entitlement of its customers, the firm's interests are sufficiently protected.
} 
costs and volume of sales are the same there as elsewhere, the chain sets prices that average 5 percent higher than in other communities. ${ }^{25}$

This hypothetical conduct was deemed unfair by $76 \%$ of respondents. Similar evidence was found for examples where prices in the monopolised geographical market were higher by $10 \%$ and $15 \%$. This suggests that a small increase is enough to be perceived as unfair, and large increases are not perceived as unfair by a larger percentage of the population or as more unfair than small increases.

In principle such a finding is in line with the aims of an effective prohibition of unfairly high pricing. Moreover, if gains and losses are considered over time, it can be argued that a higher price of a dominant firm whose position resulted from investment, innovation or superior management is not unfair, because the present gains may recoup the past opportunity costs. In contrast, if the same price is set by a firm whose dominance did not require such costs, the price may be deemed unfair. However, it is over ambitious to expect a simple principle to restrict implementation of the prohibition to situations that are unlikely to cause adverse effects regarding investment and innovation. Such consideration of adverse effects should occur long before the fairness of an individual price is considered.

The principle of dual entitlement also defines prices unfair due to factors that fall outside the remit of competition law. For instance, prices are unfair if they exploit differences in demand and supply, because in both cases a higher price also exploits gains for the firm at the expense of its customers. ${ }^{26}$ This is confirmed by the survey evidence of Kahneman et al. For example, regarding demand, it was found that $82 \%$ of survey respondents considered it unfair for a store to increase snow shovel prices the morning after a snowstorm; and regarding supply, an increase in the price of apples was deemed unfair by $63 \%$ of respondents when there was an exogenous shortage in the supply which did not affect the firm's costs. ${ }^{27}$

Separating the effects of competition and non-competition issues on price will pose two problems. First, it will increase the difficulty of using the principle of dual entitlement to determine whether a price is unfair due to competition issues. Such difficulties may be overcome by selecting an adequate reference transaction that has similar demand and (exogenous) supply conditions, but in some cases this may eliminate many of the possible prices that can be used as the reference transaction (as discussed below). Second, there may be substantial adverse effects if firms are mistakenly punished for price differences due to supply and demand. Thus, it is crucial to establish a reference transaction with similar supply and demand conditions to the transaction under investigation.

\section{Protection of reference profit at the expense of customer entitlement}

The principle of dual entitlement does not deem a price as unfair if the level is higher than the level in the reference transaction due to higher production costs. This is the case even when the terms of trade pass on the entire cost to the firm's customers, as the following example of Kahneman et al shows:

Suppose that, due to a transportation mixup, there is a local shortage of lettuce and the wholesale price has increased. A local grocer has bought the usual quantity of lettuce at a price that is 30 cents per head higher than normal. The grocer raises the price of lettuce to customers by 30 cents per head. ${ }^{28}$

Only 21\% of respondents perceived such behaviour as unfair.

This result is also in line with the goals of an effective prohibition of unfairly high pricing since as held by the General Court, 'a producer, even in a dominant position, is not obliged to sell its products below its manufacturing costs'. ${ }^{29}$ Thus, it is clear that a dominant undertaking, however inefficiently it is run, is to be permitted to recover its costs. ${ }^{30}$ It should be noted, however, that in terms of the psychology of unfairness Vaidyanathan and Aggrarwal argued that the lettuce example above does not capture the whole story, because they find that people only accept price increases if the cost rise is beyond the firm's control but such increases can be unfair if the cost rise could have been

\footnotetext{
${ }^{25}$ Kahneman et al (1986a), above n 7, at 735.

${ }^{26}$ An intervention in a market for the sake of 'fairness' due to price differences caused by demand and supply would restrict the market from working well for consumers and require the competition authority to act as a social planner.

${ }^{27}$ Kahneman et al (1986a), above n 7, 729, 734.

${ }^{28}$ Kahneman et al (1986a), above n 7, at 733.

${ }^{29}$ Case T-5/97 Industrie des Pudres Spheriques v EC Commission [2000] ECR II-3755, para 179. See below text to $\mathrm{n} 44$ for the ECJ quashing the Commission decision in United Brands for lack of showing that the firm was making profit in the relevant market.

${ }^{30}$ M. Furse, 'Excessive Prices, Unfair Prices and Economic Value: The Law of Excessive Pricing under Article 82 EC and the Chapter II Prohibition’, 4 (1) European Competition Journal (2008) 59, at 67.
} 
avoided. ${ }^{31}$ We choose to ignore such nuances in our procedure because it is likely to complicate the procedure without adding much to the legal analysis since the firm's intentions are irrelevant under the law.

Our stance also contradicts Motta and de Streel who interpret the ECJ's decision in SACEM II to mean that a price can be compared to the production costs of a hypothetical efficient firm. ${ }^{32}$ Although their argument is about establishing the excessiveness rather than the unfairness of price and is thus relevant for the first stage of the United Brands test whereas this paper is concerned with the second stage, it is worth noting that our approach excludes the use of hypothetical comparators, such as (the costs and prices of) a hypothetical efficient firm. This is because such usage breaches the fundamental principle of legal certainty by putting the dominant firm in a position where it is unable to assess the lawfulness of its activities and has for this reason already been rejected by the General Court in Deutsche Telekom. ${ }^{33}$

\section{Larger profit not at the expense of customer entitlement}

The principle of dual entitlement does not deem a price as unfair if the firm's production costs are lower but the price remains the same. This is illustrated in another of the hypothetical examples of Kahneman et al:

A small factory produces tables and sells all that it can make at $\$ 200$ each. Because of the changes in the price of materials, the cost of making each table has recently decreased by $\$ 20$. The factory does not change its price. ${ }^{34}$

Less than half of the respondents (47\%) perceived such behaviour as unfair. This was reduced to $21 \%$ if the cost had reduced by $\$ 40$ and the firm passed on half of this to its customers.

This result is aligned with the ECJ's statement in United Brands that a high price-cost margin is not enough to determine a price as unfair. It also provides dominant firms with the ability to reap the rewards of their investment in cost efficiencies. In contrast, a test that solely analyses the price-cost margin may hamper the incentives for investment in cost efficiencies, because some proportion of the saving may need to be passed through to consumers to avoid it becoming excessive. It must be noted that in British Airways the ECJ required the firm to show pass on to consumers if the firm wanted to use efficiencies as a defence for its conduct. ${ }^{35}$ Nevertheless, given that most models of monopoly and oligopoly predict that firms will pass through at least some of the cost savings to consumers, it is likely that such a requirement will be satisfied.

\section{A PROCEDURE BASED UPON DUAL ENTITLEMENT}

In Section IV.A, we develop a procedure that explicitly determines when a price is unfair in terms of dual entitlement when compared to a given reference transaction. In Section IV.B we argue that a past price of the investigated firm is the most appropriate comparator. Finally in Section IV.C we compare this procedure to the four criteria discussed in Section II to consider whether there is any improvement from following such a procedure.

\section{A. The procedure}

Figure 2 illustrates the general structure of the procedure. It may be useful to consider this as the second stage of the United Brands test in which case we can assume that the firm holds a dominant position and the first stage of the United Brands test is satisfied. Below we discuss each step in more detail.

Figure 2. Structure of the procedure

\footnotetext{
${ }^{31}$ R. Vaidyanathan and P. Aggarwal, 'Who is the fairest of them all? An attributional approach to price fairness perceptions', (2003) 56 (6) Journal of Business Research 453, at 454.

${ }^{32}$ Motta and de Streel (2007), above n 9, at 34. For SACEM II see Cases 110, 241 and 242/88 François Lucazeau and others $v$ Société des auteurs, compositeurs et éditeurs de musique (SACEM II) and others [1989] ECR 2811.

${ }^{33}$ Case T-271/03 Deutsche Telekom AG v EC Commission [2008] ECR II-477, paras 188, 192.

${ }^{34}$ Kahneman et al (1986a), above n 7, at 734.

${ }^{35}$ Case C-95/04 P British Airways plc v EC Commission [2007] ECR I-2331, para 86.
} 


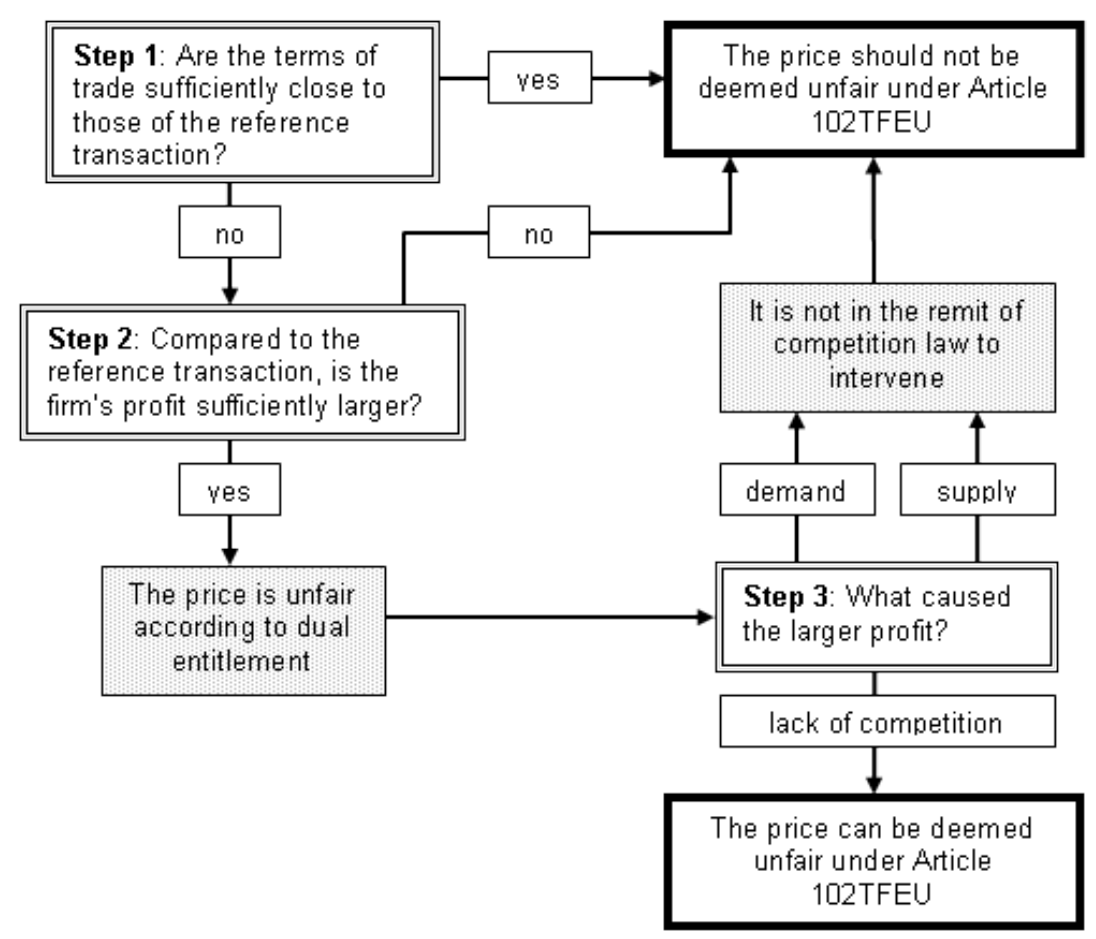

\section{Step 1}

The first step determines whether the terms of trade are significantly different to a given reference transaction. In the terminology of Figure 1, it considers whether:

$$
\Delta \mathrm{e}+\varepsilon_{\mathrm{e}}<0
$$

where $\varepsilon_{\mathrm{e}}$ is a burden of proof term to be discussed below. If the inequality in (1) is false, the firm's customers receive terms close to the reference transaction and so the price is not unfair, because customer entitlement is not sufficiently impinged compared to the reference transaction. If the inequality in (1) is true, however, we move on to the next step.

To conceptualise how to determine whether this step is satisfied, consider customer entitlement in terms of changes in expenditure to purchase the reference bundle of goods. Therefore, the comparison in (1) can be written as:

$$
\mathbf{p}_{\mathrm{i}} \mathbf{x}-\mathbf{p}_{\mathbf{r}} \mathbf{x}+\varepsilon_{\mathrm{e}}<0
$$

where $\mathbf{x}=\left(\mathrm{x}_{1}, \ldots, \mathrm{x}_{\mathrm{n}}\right)$ is the reference bundle of goods purchased, $\mathbf{p}_{\mathbf{r}}=\left(\mathrm{p}_{1}, \ldots, \mathrm{p}_{\mathrm{n}}\right)$ is the vector of prices of the reference transaction for the bundle $\mathbf{x}$, and $\mathbf{p}_{\mathbf{i}}=\left(\mathrm{p}_{1}, \ldots, \mathrm{p}_{\mathrm{n}}\right)$ is the investigated vector of prices.

For single-product firms, this comparison relates to whether the price is higher relative to the reference, which is the case for the hypothetical examples discussed in Section III.B.2-III.B.3 (when $\varepsilon_{\mathrm{e}}$ $=0$ ). For instance, in Section III.B.2 the price is unchanged so consumers do not need to expend more income to purchase the product, thus the price is not unfair despite the firm profiting from lower production costs. In Section III.B.3 customers must expend more income to purchase the same good because the firm has passed on its costs to its customers, but it is not unfair because the firm has not profited from the higher price. For multiproduct firms, this comparison relates to whether the average price of a representative bundle is higher relative to the reference. This is highlighted in the example in Section III.B. 1 where the monopolised market prices are on average 5\% higher than other competitive markets, so customers would have to expend more income in the monopolised market to purchase the same bundle of goods.

\section{Step 2}

The second step determines whether the firm has gained at its customers' expense. Again, in the terminology of Figure 1, it considers whether: 


$$
\Delta \pi-\varepsilon_{\pi}>0
$$

where, as above, $\varepsilon_{\pi}$ is a burden of proof term to be discussed below. If the firm does not gain sufficiently compared to the reference transaction, the price is not unfair. However, if the firm has sufficiently gained then the price is unfair in terms of the principle of dual entitlement, because it would lead to a situation in area $\mathrm{A}$ in Figure 1 (if $\varepsilon_{\mathrm{e}}=0$ and $\varepsilon_{\pi}=0$ ).

To conceptualise how to determine whether this step is satisfied, consider the firm's gains in terms of average profit. Thus, if the reference transaction is the firm's past price, the comparison in (3) can be rewritten such that it considers whether the difference in prices is sufficiently greater than the difference in average total costs. More formally:

$$
\mathrm{p}_{i t}-\mathrm{p}_{\mathrm{it}-1}>\mathrm{C}_{\mathrm{it}}\left(\mathrm{q}_{\mathrm{it}}\right) / \mathrm{q}_{\mathrm{it}}-\mathrm{C}_{\mathrm{it}-1}\left(\mathrm{q}_{\mathrm{it}-1}\right) / \mathrm{q}_{\mathrm{it}-1}+\varepsilon_{\pi}
$$

where in period the investigated firm i's price is $\mathrm{p}_{\mathrm{it}}$, $\mathrm{q}_{\mathrm{it}}$ is the quantity sold at such a price and $\mathrm{C}_{\mathrm{it}}\left(\mathrm{q}_{\mathrm{it}}\right)$ is firm i's costs of production. In effect, using average profit to measure the firm's relative gains considers that a firm has gained if it makes (sufficiently) more profit from its customers on average compared to the reference transaction.

Notice that using this measure captures whether the firms have gained compared to a given reference transaction (when $\varepsilon_{\pi}=0$ ) in the three hypothetical situations analysed by Kahneman et al (1986a) quoted in Section III.B.1-III.B.3. For example, regarding the situation in Section III.B.1 where a firm's prices in a monopolised market and other competitive geographical markets are compared, the quantity sold and the firm's costs are assumed to be the same in each market, so it is clear that the firm has a larger average profit in the monopolised market because the price is higher compared to the competitive markets. In the second situation in Section III.B.2 where average variable cost and price (average revenue) increase by the same amount, the firm's average profit is not larger if the quantity sold remains the same or falls. ${ }^{36}$ Finally, in the third situation in Section III.B.3 where the cost of production falls, the price is the same as the previous price, so the left-hand side of (4) is zero. Thus, the firm's average profit is larger compared to that prior to the fall in costs, because its total cost is lower but the units sold are the same.

The burden of proof terms in (1) and (3) introduce some discretion. If no such terms are included then a dominant firm that gains marginally relative to the reference transaction at a similarly small expense to its customers may be found to charge unfair prices. Therefore, including terms such that $\varepsilon_{\mathrm{e}}>0$ and $\varepsilon_{\pi}>0$ may prevent such situations from occurring. The optimal level of such terms will vary on a case-by-case basis and to a certain extent will be arbitrary in nature, but the higher such terms are, the more unlikely a price will be deemed unfair. Such terms can be used to minimise Type I or Type II errors. If the authority is more concerned about Type I (Type II) errors then it can set these terms high (low).

\section{Step 3}

The final step considers whether it is in the remit of competition law to intervene due to the unfairness of the price. Although the principle of dual entitlement deems prices unfair with respect to exogenous fluctuations in supply and demand, in our procedure prices should only be found unfair if they are unfair due to competition issues. Consequently, an abuse should only be found if the firm gains sufficiently at the expense of customers due to a lack of competition.

\section{B. The reference transaction}

A standard difficultly when drawing comparisons between prices in unfair pricing cases is the very real problem of trying to find an adequate reference price. As noted by a leading commentator, there are formidable difficulties in telling whether a price is really exploitative since the question is, by what standards this can be assessed. ${ }^{37}$ One comparator that can be used in unfairly high pricing cases is that of a price that is likely to prevail in the long-run if the market were competitive. ${ }^{38}$ Such a comparator is

\footnotetext{
${ }^{36}$ If the quantity sold decreases with the increase in price, the firm's average profit falls, because the increase in average revenue is lower than the increase in average total costs. This occurs because the firm sells fewer units but its total costs are the same as it purchased the same quantity from the wholesaler.

${ }^{37}$ R. Whish, Competition Law, (6 ${ }^{\text {th }}$ ed, Oxford: Oxford University Press 2009) 709

${ }^{38}$ See e.g. the South African Competition Appeal Court's judgment in Case No 70/CAC/Apr07 Mittal Steel South Africa Ltd v Harmony Gold Mining Company Ltd (29 May 2009) para 40.
} 
not free from problems because complexities arise due to the estimation of such a price and determination of the 'unacceptable' profit margin above such a price. To avoid such difficulties and to be consistent with the approach taken in the surveys of Kahneman et al (1986a), we choose to focus on comparisons with present or past prices of similar products sold by the investigated firm or its rivals. This approach is also consistent with the European case law as the ECJ has established that making such comparisons is a valid technique for determining unfairness, so long as the comparisons are made on a consistent basis. ${ }^{39}$

For such comparisons, there are four possible types of prices that can be used as the reference transaction. The first two are prices charged by the dominant firm in the past on the investigated market or current prices on comparable yet separate markets. The other two regard rivals' prices such as current prices of similar products in the investigated market or in separate markets. The use of any of these reference points will not be without its problems. Examples of such problems include the reference price itself being unfairly high or at least not competitive, the characteristics of the reference market possibly meaning that its prices are inappropriate comparators for the investigated market, or the lack of an appropriate comparator. We believe that the comparator that has the greatest potential to overcome such problems and to provide the most informative comparison is a past price charged by the dominant firm in the investigated market, for the reasons explained below. The other three comparisons may still be useful to highlight that the finding of unfairness is robust to other reference points and as an alternative if a past price is an inadequate comparison.

In the case law past prices of the investigated firm have not always been used as a comparison, even though this seems to be a natural interpretation of whether a price is 'unfair in itself' as set out by the ECJ in the second stage of the United Brands test. ${ }^{40}$ In fact, as the next section shows, using the past price as the main comparator appears to be apt at capturing the outcome in the actual decisions examined. One benefit that a past price has compared to the other possible reference prices is that it will be more likely that an adequate comparator exists. Such a comparator will not exist if the product is new, but it is questionable whether the prohibition should be applied in such circumstances because it is likely to have serious implications for investment and innovation. In contrast, the other three comparisons may be ruled out quite easily in many situations. For instance, using a competitor's price in the investigated market as a comparator will not be possible if such competitors do not exist. This will be the case if the investigated firm is super-dominant on the investigated market. Even if competitors do exist in the investigated market, it is debatable whether an abuse should be found, as it will be uncertain as to whether the investigated firm's high price will be sustained in the long run given such competitive constraints. Moreover, there must be some objective cause for the price difference such as (vertical or horizontal) differentiation, cost asymmetries or differences in capacities which the competition law enforcer should avoid interfering with. Using prices (whether the investigated firm's or its competitors) on a similar product or geographical market as the reference price is likely to be extremely difficult because they are likely to have substantially different demand and/or cost structures.

Using a past price of the investigated firm as a comparator will be most informative when the investigated price is compared to a price set prior to the point where the firm became dominant. Such a price has the potential to provide a direct comparison of how much the price has changed due to the lack of competition. Of course, this may not be possible if the firm has been dominant for a long period of time and as a result the firm's prices in the recent past do not provide an adequate competitive benchmark. However, this is unlikely if the prohibition is only applied in situations where dominance has been achieved through anticompetitive means or where there were previous investigation failures, as proposed by Röller. ${ }^{41}$ Using prices prior to the anticompetitive action or investigation failure as the reference price will be less reasonable the further in the past are such prices since demand factors and production costs will vary over time. Yet, this is still likely to be more informative than using a comparison of different products in different geographical markets which in general are unlikely to have similar demand factors and production costs even in the same time period.

\section{The effective test criteria}

In this subsection, we compare the procedure to the criteria for an effective test of unfairly high pricing discussed in Section II to consider how it may improve the second stage of the United Brands test.

\section{Clear definition}

\footnotetext{
${ }^{39}$ See e.g. Case 30/87 Bodson v Pompes Funébres des Régions Libéréés [1988] ECR 2479, para 31; Case 395/87 Ministère Public v Tournier [1989] ECR 2521, para 38; SACEM II, n 32 above, para 25.

${ }^{40}$ This interpretation differs to that of the European Commission in Scandlines (see Section V.C)

${ }^{41}$ See Röller, above n 18.
} 
The procedure developed above is well-defined as it is based on a principle built on the 'unfairness' perception of the members of society. It can explain when and why prices are unfair relative to comparable prices. This is an improvement on the United Brands test which leaves open the definition of unfairness in the second stage.

\section{Ex ante legal certainty}

The procedure provides greater legal certainty than the current law, because firms know that their past prices will be the most prominent comparator. Therefore, firms will be aware that if they set prices significantly higher than the recent past, such prices risk being found abusive if they are caused by a lack of competition. Further legal certainty can be provided by announcing levels of $\varepsilon_{\mathrm{e}}$ and $\varepsilon_{\pi}$ ex ante. However, such levels will be set arbitrarily and this may not be preferable over determining them on a case-by-case basis.

\section{Simplicity}

It should be relatively simple to use this procedure: a comparison should exist in most cases and the steps involved do not require complex analysis. It is a particularly simple exercise to consider whether customers' entitlement has been impinged when the firm's product has not changed over time. One problem that is not addressed by this measure is that it does not take account of non-price factors, such as the product's quality. Thus, if there are changes to the product over time, the analysis may also require subtle trade-offs between price and non-price factors, which may add a degree of complexity. The most complicated aspect is likely to be the determination of whether the firm has gained, especially if the firm's production costs differ over the period of comparison. Further complications will arise if the firm is a multiproduct or multimarket firm, because it will be difficult to determine how common costs are allocated among different products. Nevertheless, these complications would not necessarily be more difficult than under the current system which involves similar parameters.

\section{Improve welfare}

Using our procedure has the potential to increase the likelihood that a case will be successful, which may increase welfare in the exceptional circumstances where the prohibition should be applied. On the other hand, it also has the potential to lead to Type I errors if it is not followed correctly or applied in inappropriate situations. To minimise the potential for such errors, a competition authority could place a high burden of proof in the first two steps, so that a price is unfair only in situations where the firm has gained substantially and/or when customers have been severely harmed. A further problem is that using price comparisons has the potential to lead the firm that controls the reference to use it as a strategic variable to benefit itself. For instance, when the reference is a past price of the investigated firm, an expectation that a price set today could be used as the reference in the future may provide the firm with an incentive to set higher prices today than it would otherwise. Nevertheless, if the prohibition is used for exceptional circumstances, any such incentives to adjust prices strategically may be small.

\section{ILLUSTRATIONS FROM THE CASE LAW OF UNFAIRLY HIGH PRICING}

In this Section, we discuss three European unfairly high pricing cases to highlight the presence or absence of similarities with the procedure developed above. This illustrates how this procedure may work in practice and considers, from the information available in the decisions, whether it would lead to the same decisions as those found. The cases have been chosen due to their importance in developing the current test that is used for unfairly high pricing. The first is United Brands in which the ECJ spelled out a test for the abuse. The second is British Leyland which is the only ECJ judgment that confirmed a finding of an abuse by the Commission. The third is Scandlines in which for the first time the Commission has elaborated on its own method of assessment.

\section{A. United Brands}

In 1978, the Commission found that United Brands had charged unfairly high and discriminatory prices for its 'Chiquita' brand bananas in a geographical market including Belgium, Luxembourg, Denmark and Germany. United Brands was the largest banana group in 1974 accounting for 35\% of all banana 
exports on the world market and approximately $45 \%$ of the relevant market. In the investigation, the Commission made three comparisons to establish whether the prices were unfair. First, it found that prices for Chiquita bananas in Germany, Denmark, Belgium and Luxembourg were sometimes 100\% higher than the prices of the same product in Ireland. Second, there was a $20-40 \%$ difference between the prices of Chiquita and unbranded bananas in the relevant geographical market, but the quality of the latter was slightly lower than the former. ${ }^{42}$ Third, the prices of similar quality unbranded bananas sold by competitors in Germany, Denmark, Belgium and Luxembourg were lower than those of Chiquita brand bananas.

Although the Commission did not focus on past prices charged by United Brands (something that was eventually criticised by the ECJ), it is possible to highlight the first two steps of our procedure using the comparison of prices in Ireland relative to those in Germany, Denmark, Belgium and Luxembourg. For instance, in the first step, it is clear that the consumers would have to spend substantially more in the investigated market than in Ireland to receive the same product. It is more difficult to argue this for the other comparisons because it is possible to justify the price differences in terms of perceived quality. Similar to the second step of our procedure, the Commission argued that the price in Germany, Denmark, Belgium and Luxembourg was unfairly high compared to that in Ireland, because the latter yielded (accounting) profit. ${ }^{43}$ This is because, reading between the lines, it seems as though the Commission implicitly assumed that, since the low price in Ireland was profitable, the higher price in the relevant market would make a greater profit. However, such an inference would only be true if the firm's costs for the two markets were not substantially different, so to satisfy the second step of our procedure there needed to be some discussion as to whether the costs on the two markets were similar.

The ECJ overturned the Commission's finding because the Commission had failed to determine whether United Brands was making profit in the relevant market and had not taken into account that the prices in Ireland may have produced losses. ${ }^{44}$ Thus, this instigated the ECJ to include the excessive price-cost margin criterion in the first stage of the United Brands test. The ECJ also held that the Commission's claim that the prices were unfair could be criticised, because for nearly 20 years prior to the investigation banana prices had not risen in real terms. ${ }^{45}$ This criticism is consistent with our procedure because the past price of the investigated firm is our preferred reference point. Therefore, since prices had not increased over time, if the firm had gained over the period it had not done so at its customers' expense. Hence, the first step of the procedure would not be satisfied, and consequently the price would not be deemed as unfair in terms of our procedure.

\section{B. British Leyland}

In Great Britain the manufacturer of a vehicle must apply for a British national-type-approval (NTA) certificate proving that the vehicle complies with legally required standards, and importers must obtain a 'certificate of conformity' certifying that the vehicle conforms with such standards. This certificate can be issued by the car manufacturer (if the vehicle has an approved NTA certificate), or obtained at great cost from the Department of Transport with the car manufacturer's cooperation. In 1982, British Leyland, the second largest British car manufacturer, charged unfairly high and discriminatory prices for certificates of conformity to some importers of its recently launched Metro, and refused to supply such certificates on occasions to some importers. Specifically regarding prices, British Leyland raised the fee to distributors for certificates of conformity for left-hand-drive Metros (which were considerably cheaper on the continent than in Britain) from $£ 25$ to $£ 150$ to make re-imports to Great Britain less attractive. The charge for private individuals and right-hand-drive vehicles remained at $£ 25$, however. According to the ECJ, the difference between the fees for left-hand and right-hand drive vehicles meant that the fee was disproportionate to the economic value of the service provided and therefore abusive. ${ }^{46}$

Such conduct would also be deemed unfair by our procedure. For example, when comparing the fee over time, it is clear that customers have to spend more to purchase the certificate after the increase, so the first step is satisfied. Regarding the second step it is also clear that the left-hand side of (4) is positive, so all that is required is a discussion of whether costs differed. The Commission dismissed British Leyland's claim that the fee increase resulted from a rise in costs, highlighting British Leyland's later decision to reduce the charge to traders of left-hand-drive vehicles to $£ 100$ whilst at the

\footnotetext{
${ }^{42}$ United Brands, above n 1, paras 239-240.

${ }^{43}$ United Brands, above $\mathrm{n} 1$, paras 236-237.

${ }^{44}$ United Brands, above n 1, paras 250, 251, 256, 261.

${ }^{45}$ United Brands, above n 1, paras 265-266.

${ }^{46}$ Case 226/84 British Leyland plc v EC Commission [1987] 1 CMLR 185, 222.
} 
same time increasing the charge to private individuals of left-hand-drive vehicles to $£ 100$. Furthermore, the ECJ elaborated later in the dismissed appeal, that issuing the certificate 'cannot entail significant costs' since it merely consisted of determining the date of manufacture of the vehicle and then identifying the number of the corresponding NTA certificate. ${ }^{47}$ Consequently, given there is no substantial difference in the costs, we can establish that British Leyland gained at its customers' expense. In the final stage, since there is no suggestion that the price increase was due to changes in demand or supply, we can only surmise that it was due to the exploitation of market power, so in terms of our procedure the price could be deemed unfair when compared to the past price. A similar conclusion is drawn if the fee for left-hand-drive vehicles is compared to the fee for right-hand equivalents.

It must, however, be noted that, although this case provides an interesting example regarding our procedure, the abuse resulted from exclusionary conduct rather than exploitative, as through its unfairly high price British Leyland segregated the Common Market which is fundamentally against the 'single market imperative' of the EU which seeks to integrate the European markets. Given the problems regarding the unfair pricing prohibition it is questionable whether the Commission should follow such a strategy in the future, not least because doing so is unnecessary as such conduct can be dealt with other parts of Article 102TFEU that have been used to sanction exclusionary conduct.

\section{Scandlines}

The port of Helsinborg in Sweden and its counterpart in Denmark, Elsinore, provide the shortest crossing distance between Sweden and Denmark. In 2004, Scandlines, a ferry operator, alleged that the charges of HHAB (operator of Helsinborg) for services provided to ferry operators did not reflect the actual costs borne by HHAB for such services, so were unfairly high. To determine an abuse, the Commission followed the two-staged United Brands test, but it did not establish whether HHAB's price-cost margin was excessive in the first stage, because it argued that the second stage of the test was not satisfied.

In the second stage, it found that there was insufficient evidence that prices were unfair in themselves or relative to other comparable prices. The number of possible comparisons was limited because HHAB held a monopoly on the relevant market, so there were no substitutable services provided by competitors, and a comparison of competitive prices charged to cargo vessels was inadequate, because such operations were run at a loss. ${ }^{48}$ The Commission did find that HHAB's charges were on average 3.6 times higher than the charges Scandlines would have paid in Elsinore, ${ }^{49}$ but the level of costs in Elsinore was nearly seven times lower than in Helsingborg. ${ }^{50}$ Due to such cost differences, the Commission argued that this comparison was also inadequate. In contrast, the small price difference in comparison to the large cost difference would raise serious doubts as to whether HHAB gained at the expense of its customers in the second step of our procedure.

The Commission went on to consider whether the price was 'unfair in itself'. Instead of analysing prices over time as we propose, the Commission interpreted this as whether the charges had no reasonable relation to the 'economic value' of the product. Thus, in doing so, it confused the definition of an abuse with a stage of the United Brands test. Although this concept has been discussed in terms of the test in other cases, most seem to equate the 'economic value' of a product with the cost of production, so it is usually mentioned in the price-cost analysis in the first stage of the United Brands test. ${ }^{51}$ However, the Commission argued that HHAB's charges were not unfair in themselves because the economic value of the services also includes additional costs and other factors such as very high sunk costs of the port of Helsingborg, the opportunity cost of the land where the port was situated and the benefit to ferry-users due to the ideal location of the port. ${ }^{52}$ Such an interpretation creates a problem for the prohibition because if demand-side factors contribute to the economic value of the product, then in all cases it could be argued that any price must reflect its economic value to a buyer since otherwise

\footnotetext{
${ }^{47}$ British Leyland, above n 46, 221-222.

${ }^{48}$ Scandlines, above n 3, paras 170,176-179.

${ }^{49}$ Scandlines, above n 3, para 182.

${ }^{50}$ Scandlines, above n 3, para 183.

${ }^{51}$ See General Motors Continental NV v EC Commission [1975] ECR 1367, paras 12, 22; British Leyland, above n 46, paras 2830; Deutsche Post AG - Interception of cross-border mail [2001] OJ L331/40, paras 162, 163-164, 166. However, in CICCE, the ECJ upheld the Commission's decision which found that 'abuse depended on the relationship between the cost and the economic value of the service provided' which suggests that economic value and cost might not be equivalent; Case 298/93 Comite des industries cinematographiques des Communautes europeennes (CICCE) v EC Commission [1985] ECR 1105, para 74.

${ }^{52}$ Scandlines, above n 3, para 209.
} 
there would be no sale. ${ }^{53}$ Our interpretation of 'unfair in itself' as unfair when compared to the price of the firm in the past avoids such a problem, because it relies on whether the firm has substantially increased its profit on average over time rather than considering how the product is valued.

\section{CONCLUSION}

This paper contributes to the literature on resolving the problems with the unfair pricing prohibition under Article 102TFEU. As such, it also contributes to EU competition law and policy by proposing an improvement on the interpretation of the existing law. Specifically, it shows that using the principle of dual entitlement to determine a price as unfair relative to other comparable prices is generally in line with the goal of an effective prohibition of unfairly high pricing. Using this principle, a procedure is developed to define explicitly whether a price is unfair in the second stage of the United Brands test, and this compares favourably with the existing case law. If followed, this procedure may help to improve the ex ante legal certainty of the test and in turn lead to a more effective prohibition.

The aim of this paper is to attempt to improve how one part of the law is interpreted as it currently stands, given that an amendment to the Treaty is very unlikely in the near future. Due to the large number of problems regarding the abuse of unfair pricing, for the longer term where an amendment to the Treaty may become more likely, it will be necessary for policymakers to go further than such a short term solution by reconsidering more generally how exploitation is dealt with in Article 102TFEU. This would entail questioning whether it is appropriate for competition authorities to intervene with regard to exploitation at all and, if it is decided that it is, reconsidering whether focussing on prices is the optimal way to target such abuse. This implies that it may be necessary to reassess whether relying on behavioural remedies rather than structural remedies to resolve problems of exploitation is the optimal practice since behavioural remedies in this case force competition authorities and courts to act as price regulators which is a role that the European Commission has rightly been reluctant to play. However, until such changes occur in the approach of the competition authorities and/or in the law, the procedure proposed in this paper can improve the current interpretation of unfairly high pricing and contribute to a better application of Article 102TFEU.

\footnotetext{
${ }^{53}$ Similarly see E.M. Fox, 'Monopolization and Dominance in the United States and the European Community: Efficiency, Opportunity, and Fairness’, (1986) 61 (5) Notre Dame Law Review 981, at 993.
} 